\title{
INCREASING THE SURFACE HARDNESS OF CAST IRON BY ELECTRODEPOSITION OF BORIDES IN MOLTEN SALTS
}

\begin{abstract}
In this paper the electrodeposition of boron on the surface of cast iron as a coating is applied to increase the hardness and protect the substrate against abrasive wear. The boron containing coating was synthesized by electrodeposition process from a $\mathrm{NaCl}-\mathrm{KCl}(1: 1 \mathrm{~mol})-10 \mathrm{w} \% \mathrm{NaF}-10 \mathrm{w} \% \mathrm{KBF}_{4}$ molten salt. The effect of electrolysis parameters (temperature and time) on the hardness is presented; the current density varied in the range $-37--4.5 \mathrm{~mA} / \mathrm{cm}^{2}$, allowing perfect coverage of and respect for dimensions. The electrochemical process was carried out at different temperatures $\left(750^{\circ} \mathrm{C}-900^{\circ} \mathrm{C}\right)$ and for different periods of time (5-10 hours). Depending on the current density and duration of electrolysis, the deposits consist of $\mathrm{FeB}$ or $\mathrm{Fe}_{2} \mathrm{~B}$. Microhardness measurements across the boride layer indicated very high hardness values (between 1600 and $2100 \mathrm{HV} 0.05$ ). The structure of the boride layer is linked to its boron content and thermal history: as-deposited coatings present very small grain sizes and can be considered as nearly amorphous.
\end{abstract}

Keywords: electrodeposition, boron, cast iron

\section{Introduction}

Borides are a large class of chemical compounds having very promising properties but relatively narrow applications in technology today. Boride layer can be obtained on iron and steel substrates either by electrolysis in molten salts or by thermochemical process. The principal advantage of the electrolytic process for simple shape substrates (rods, plates, sheets) is that very high rates of the boride layer growth can be achieved [1]. The electrochemical boriding of metals in molten salts using the cathode discharge of complex fluorides such as $\mathrm{KBF}_{4}$ from a fluoride bath is known to be an interesting method of obtaining very hard layers on the surface [2]. Molten salts generally can be considered as a very promising medium for chemical and electrochemical synthesis of different compounds. The electrodeposition of refractory metals [3], refractory borides [4] and borides of lower melting point metals, e.g. $\mathrm{MgB}_{2}$ [5] was reported in literature. Segers et al. [1] wrote about the electrochemical boriding of iron from a molten salt. Sodium tetraborate $\left(\mathrm{Na}_{2} \mathrm{~B}_{4} \mathrm{O}_{7}\right)$ and $\mathrm{Na}_{2} \mathrm{~B}_{4} \mathrm{O}_{7}-\mathrm{NaCl}$ mixture were used as electrolyte in their research. They reported that the hardness of $\mathrm{FeB}$ was $\sim 1800 \mathrm{HV} 0.1$ and that of $\mathrm{Fe}_{2} \mathrm{~B}$ was $\sim 1200 \mathrm{HV} 0.1$. Kartal et al [6] also reported a $\mathrm{Na}_{2} \mathrm{~B}_{4} \mathrm{O}_{7}-\mathrm{NaCl}$ mixture, halogencontaining compounds (mainly $\mathrm{KBF}_{4}$ ) and boron oxide $\left(\mathrm{B}_{2} \mathrm{O}_{3}\right)$ as electrolyte [7].
Currently, the main methods of obtaining materials of different functionality are the methods of physical and chemical vapor deposition, self-propagating high-temperature synthesis (SHS). Austempered ductile cast iron (ADI) has emerged as a major engineering material in recent years because of its excellent mechanical properties; these include high strength with good ductility, good wear resistance and fatigue strength. It is therefore considered as an economical substitute for wrought or forged steel in several structural applications. The attractive properties of ADI are related to its unique microstructure that consists of ferrite $(\alpha)$ and high carbon austenite $(\gamma \mathrm{HC})$. This is different from the austempered steels, where the microstructure consists of ferrite and carbide. Because of this difference, the product of austempering reaction in ductile iron is often referred to as "ausferrite" rather than bainite [8]. Large amount of silicon present in ductile iron suppresses the precipitation of carbide during austempering reaction and retains substantial amount of stable high carbon austenite $(\gamma \mathrm{HC})$.

The purpose of this contribution is to study the process of electrochemical boriding of austempered ductile cast iron (ADI) in molten alkali chloride-fluoride mixtures in the range of temperatures $750-900^{\circ} \mathrm{C}$.

\footnotetext{
* UNIVERSITY OF MISKOLC, DEPARTMENT OF NANOTECHNOLOGY, MISKOLC-EGYETEMVÁROS, H-3515, HUNGARY

** GEDEON RICHTER PLC., 19-21 GYÖMRÖI ST., BUDAPEST, HUNGARY, 1103

*** BAY ZOLTÁN NONPROFIT LTD. FOR APPLIED RESEARCH, ENGINEERING DIVISION (BAY-ENG), IGLÓI 2., MISKOLC, H-3519, HUNGARY 


\section{Experimental techniques}

\subsection{Materials and methods}

The measurements were carried out in an air-tight electrolytic cell made of an INCOLOY super alloy (Fig. 1). Sodium chloride, potassium chloride, sodium fluoride and potassium tetrafluoroborate (all reagent grade, Sigma-Aldrich) were used for the measurements. Prior to experiments, the salt mixture $\left(\mathrm{NaF}-9.678 \mathrm{~g}, \mathrm{KBF}_{4}-9.678 \mathrm{~g}, \mathrm{NaCl}-42.591 \mathrm{~g}\right.$ and $\mathrm{KCl}$ - $54.210 \mathrm{~g}$ ) was weighed in a glassy carbon crucible (HTW Hochtemperatur-Werkstoffe $\mathrm{GmbH}$ ) which was placed in the bottom of the electrolytic cell and thoroughly dried in vacuum at a temperature of $120^{\circ} \mathrm{C}$ for $99 \mathrm{~h}$. After that the temperature was raised to $300^{\circ} \mathrm{C}$ and held for $1 \mathrm{~h}$. To enhance the moisture removal, periodic flushing with purified dry argon gas was applied. After that the salts were melted in argon. The electrolysis was performed in potentiostatic regime at $750^{\circ} \mathrm{C}$ and $900^{\circ} \mathrm{C}$, with a cast iron ADI cathode $(26.25 \mathrm{~mm}$ long, $14.02 \mathrm{~mm}$ wide and $2.78 \mathrm{~mm}$ thick cast iron ADI plate, active surface area: $7.4 \mathrm{~cm}^{2}$, initial mass: $6.849 \mathrm{~g}$ ). The cathode was attached to a molybde-

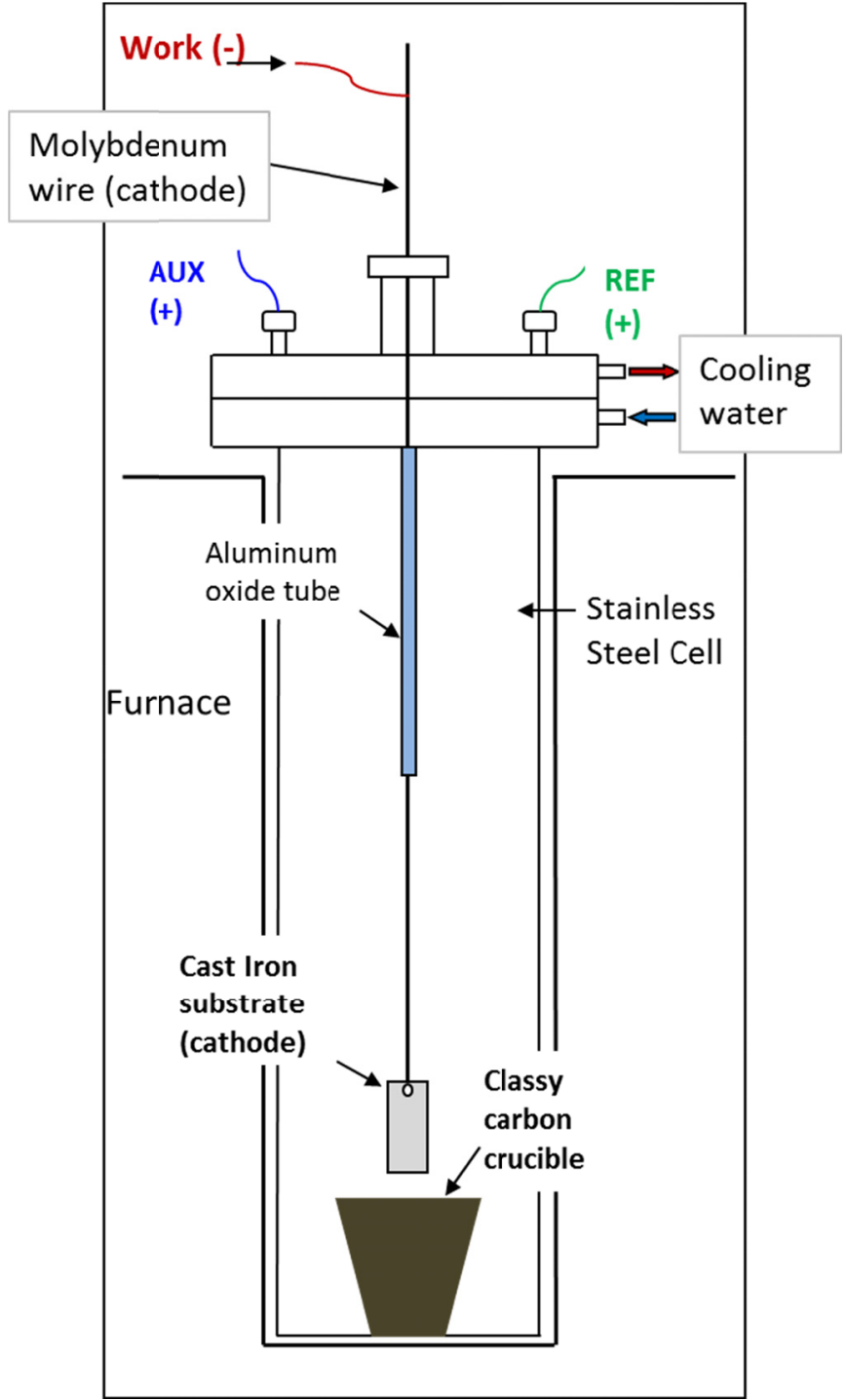

Fig. 1. Electrodeposition cell num wire of $1 \mathrm{~mm}$ in diameter (current lead) shielded with an aluminum oxide tube. The glassy carbon crucible was used as the anode. The potential difference between the cathode and the anode was fixed at $1200 \mathrm{mV}$ using a Radiometer Analytical VoltaLab 40 "dynamic electrochemical laboratory". The duration of electrolysis was $5 \mathrm{~h}$ and $10 \mathrm{~h}$.

After the electrolysis, the surface of the samples was cleaned in an ultrasonic bath containing distilled water.

$\mathrm{X}$-ray diffraction phase analysis (XRD) was performed with a $40 \mathrm{kV} 40 \mathrm{~mA}$ Bruker D8 Advance diffractometer using a Co tube.

The hardness of the borided iron sample surface was investigated by a Mitutoyo MVK H1 Vickers microhardness tester with a load of $50 \mathrm{~g}$ and $100 \mathrm{~g}$.

\section{Results and discussion}

A typical chronoamperogram recorded during the electrolysis is shown in Fig. 2. The "drop" of current observed in the first few minutes after switching the potential, is due to the depletion of boron ions from the electrolyte layer being in the direct contact with the cathode (setting the steady state of electrochemical process). Further decrease of the current may occur for different reasons, e.g. lower total electric conductivity of boron and boride phases being on the sample surface compared to that of pure ADI; different state of the electrode surface covered with boron/ borides is going to shift the equilibrium electrode potential and thus change the difference between the actual electrode potential and the equilibrium one, resulting in different deposition current at the same cell potential, etc.

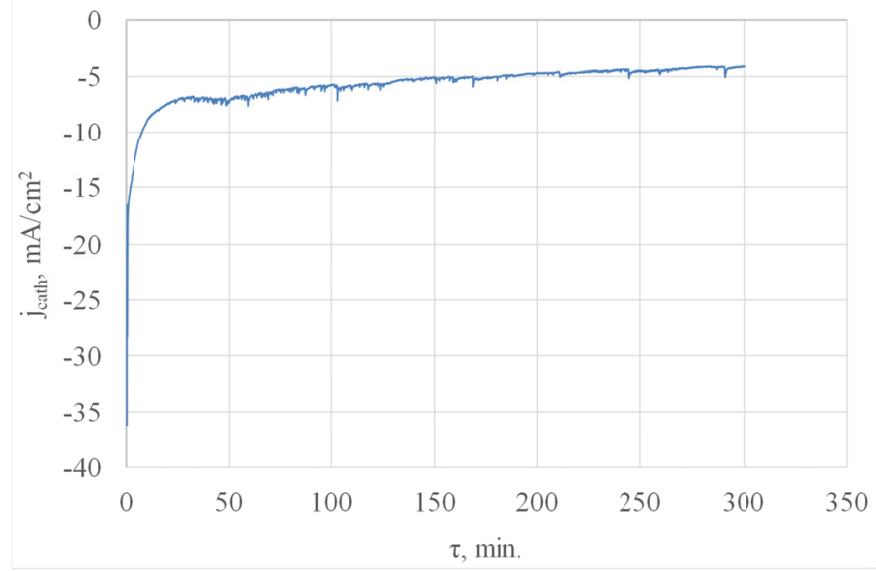

Fig. 2. Current density as function of electrolysis time

After the electrodeposition, the hardness of the samples was investigated. The results are shown in Figs. 3, 4.

It can be concluded from Fig. 3 and Fig. 4 that the value of hardness increases with the time of electrodeposition. After 5 hours of electrolysis the hardness is $1180 \pm 40 \mathrm{HV}_{0.05}$ both at $750^{\circ} \mathrm{C}$ and $900^{\circ} \mathrm{C}$. We found no temperature effect on the hardness after 5 hours of electrolysis. At $900^{\circ} \mathrm{C}$ the hardness depends 


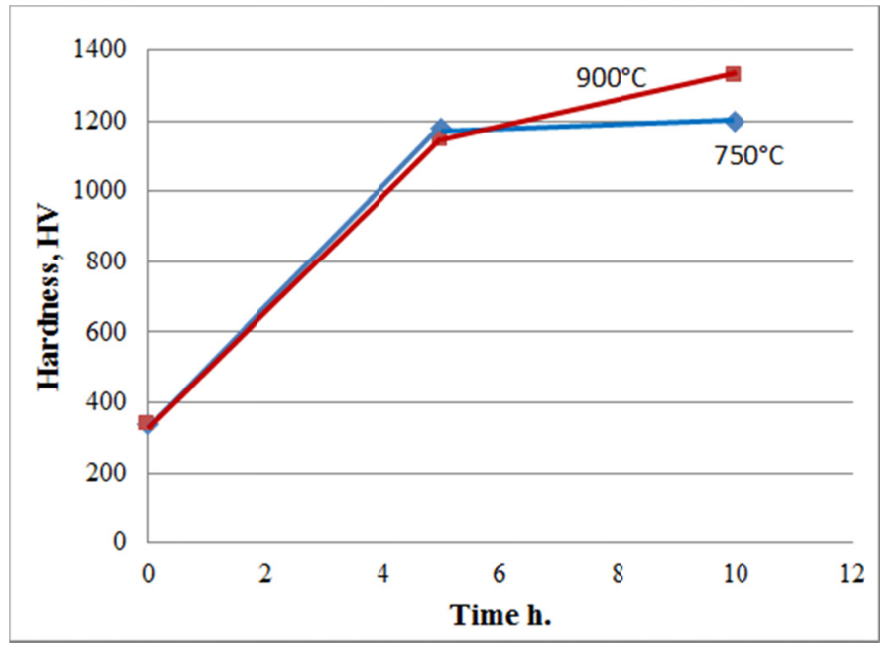

Fig. 3. Hardness of the borided cast iron as function of electrolysis time at $750^{\circ} \mathrm{C}$ and $900^{\circ} \mathrm{C}$

upon the electrolysis time; after 10 hours of electrolysis the hardness is $1330 \pm 40 \mathrm{HV}_{0.05}$, being higher than after 5 hours of electrolysis. According to the XRD measurements (Fig. 5), a single phase $\left(\mathrm{Fe}_{2} \mathrm{~B}\right)$ coating is formed on the surface of ADI at both electrolysis temperatures. After 10 hours of electrolysis at $900^{\circ} \mathrm{C}$ a double phase (FeB layer upon $\mathrm{Fe}_{2} \mathrm{~B}$ layer) coating is formed.

\section{Conclusion}

The results described in this work show that boriding of cast iron (ADI) substrates is possible and the only boride phase formed on the surface after 5 hours of electrolysis at both $750^{\circ} \mathrm{C}$ and

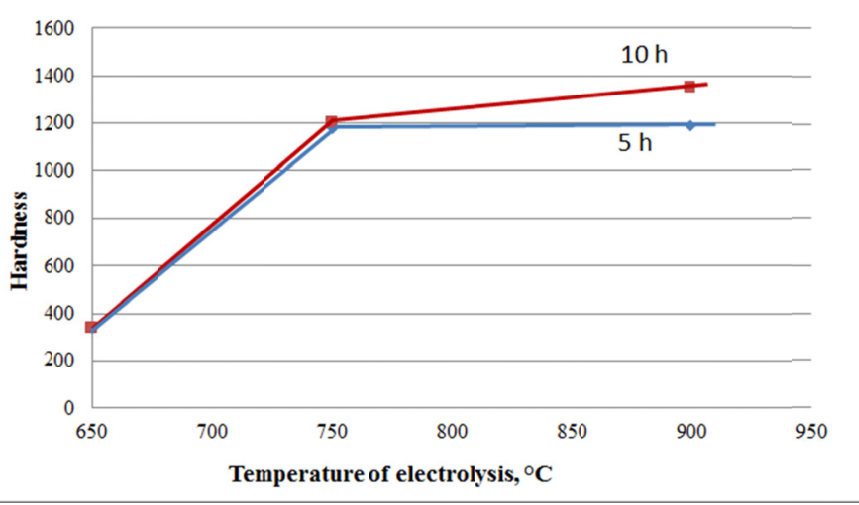

Fig. 4. Hardness of the borided cast iron as function of electrolysis temperature after 5 hours and 10 hours of electrolysis

$900^{\circ} \mathrm{C}$ is $\mathrm{Fe}_{2} \mathrm{~B}$. After 10 hours of electrolysis at $900^{\circ} \mathrm{C}$ a double phase $\left(\mathrm{FeB}-\mathrm{Fe}_{2} \mathrm{~B}\right)$ coating is formed on $\mathrm{ADI}$ cast iron. The hardness of the single phase $\mathrm{Fe}_{2} \mathrm{~B}$ coating is $1180 \pm 40 \mathrm{HV}_{0.05}$, while that of the double phase $\mathrm{FeB}-\mathrm{Fe}_{2} \mathrm{~B}$ coating is $1330 \pm 40 \mathrm{HV}_{0.05}$, which is in reasonable agreement with the literature data.

\section{Acknowledgement}

The authors are thankful to Dr. Marton Benke for the XRD measurements and to Mrs. Agnes Balogh Csurilla for the hardness measurements. The research work of P. Baumli was supported by the János Bolyai Research Fellowship of the Hungarian Academy of Sciences.

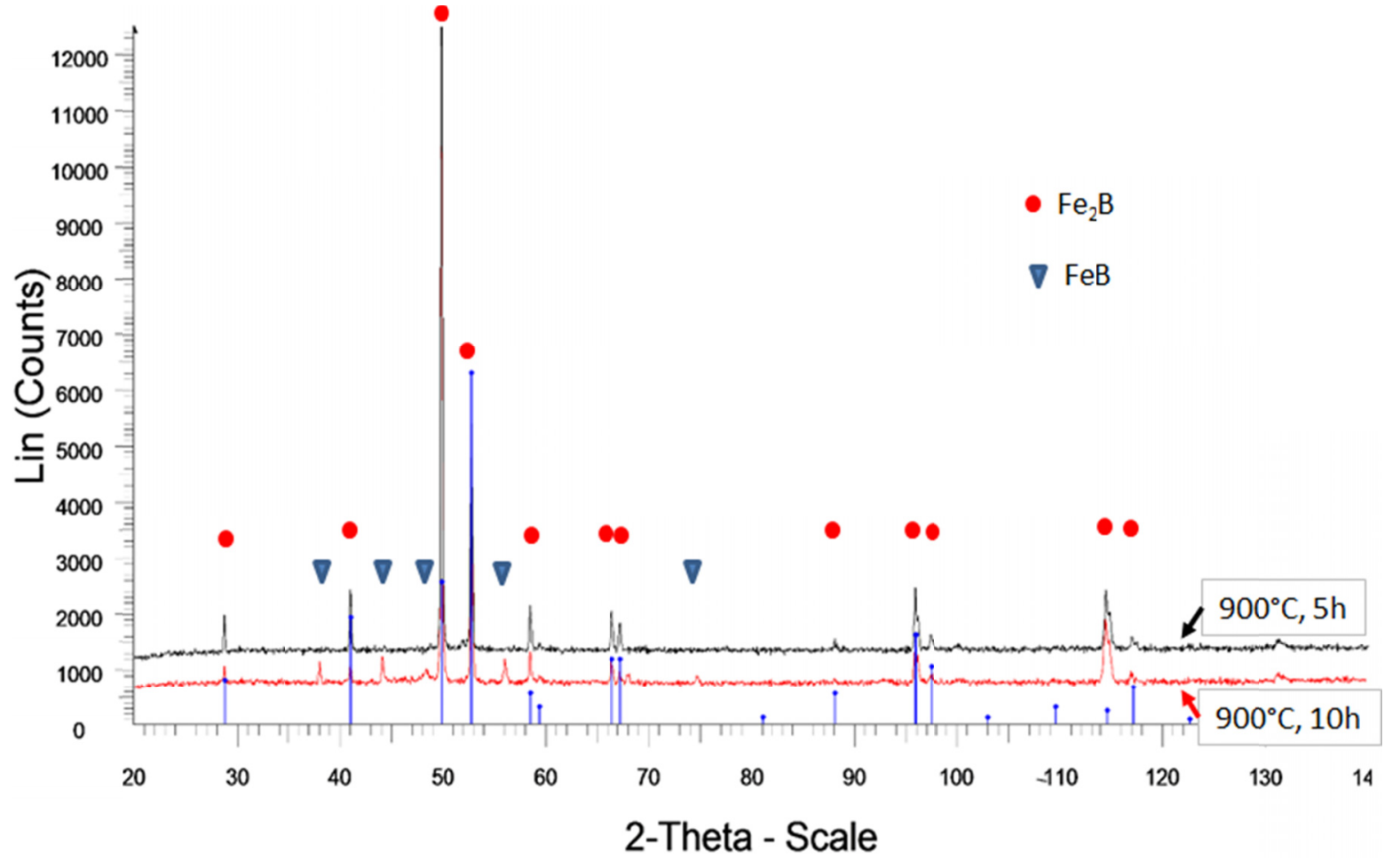

Fig. 5. X-ray diffraction patterns of borided cast iron $\left(t=900^{\circ} \mathrm{C}\right.$, electrolysis time: 5 and 10 hours $)$ 


\section{REFERENCE}

[1] L. Segers, A. Fontana, R. Winand, Electrochimica Acta 36 (1), 41-47 (1991)

[2] A. Bonomi, R. Habersaat, G Bienvenu, Surface Technology 6 (4), 313-319 (1978)

[3] A. Girginov, T.Z. Tzvetkoff, M. Bojinov, Journal of Applied Electrochemistry 25 (11), 993-1003 (1995).

[4] G. Kaptay, S.A. Kuznetsov, Plasmas \& Ions 2 (2), 45-56 (1999).
[5] H. Abe, K. Yoshii, K. Nishida, M. Imai, H. Kitazawa, Journal of Physics and Chemistry of Solids 66 (2-4), 406-409 (2005).

[6] G. Kartal, S. Timur, C. Arslan, Journal of Electronic Materials 34 (12), 1538-1542 (2005).

[7] Guldem Kartal Sireli, Encyclopedia of Iron, Steel, and Their Alloys, Chapter: Molten Salt Baths: Electrochemical Boriding, Publisher: CRC Press -Taylor \& Francis Group, Editors: Rafael Colás, George E. Totten, DOI: 10.1081/E-EISA-120052671.

[8] S.K. Putatunda, Materials Science and Engineering 315 (1-2), 70-80 (2001). 